\title{
AKTIVITAS ANTI-INFLAMASI EKSTRAK ETANOL TEPUNG PELEPAH AREN (Arenga pinnanta)
}

\author{
Devy Angreani $\mathrm{M}^{1}$, Meiske S. Sangi ${ }^{1}$, Feti Fatimah ${ }^{1}$ \\ ${ }^{1}$ Program Studi Kimia Fakultas Matematika dan Ilmu Pengetahuan Alam Universitas Sam Ratulangi Manado
}

\begin{abstract}
ABSTRAK
Tepung pelepah aren secara tradisional digunakan sebagai obat untuk menghilangkan rasa gatal dan luka bakar pada kulit. Penelitian ini bertujuan untuk menguji aktivitas anti-inflamasi ekstrak etanol tepung pelepah aren (Arenga pinnanta) menggunakan metode induksi karagenan. Ekstrak etanol tepung pelepah aren yang digunakan didapatkan dari hasil maserasi tepung pelepah aren menggunakan etanol hasil redestilasi cap tikus. Metode pengujian aktivitas anti-inflamasi menggunakan 15 ekor tikus putih jantan galur wistar dengan berat 150200 gram yang dibagi dalam 5 kelompok perlakuan, Kelompok Kontrol negative, Kontrol Positif dan kelompok dosis ekstrak etanol 20\%, 25\% dan 30\%. Hasil penelitian ini menunjukkan kelompok ekstrak etanol tepung pelepah aren dosis 30\% memiliki kemampuan inhibisi udem yang sama dengan kontrol positif (Na Diklofenak) dan memiliki kemampuan inhibisi yang lebih besar dibandingkan dosis $20 \%$ dan $25 \%$.
\end{abstract}

Kata Kunci : Pelepah aren, Metode Induksi Karagenan, Anti-Inflamasi

\section{ABSTRACT}

Palm stem flour is traditionally used as a remedy for the relief of itching and burns on the skin. This research aims to test the anti-inflammatory activity of palm-flour (Arenga pinnanta) ethanol extract using Caragenan induction method. Palm-dried stem flour extract used from the maceration of palm flour, using ethanol redestilation of rat seals. The method of testing anti-inflammatory activity using 15 male white rats with Wistar strain with a weight of 150-200 grams divided into 5 treatment groups, negative control group, positive control and group dose of ethanol extract $20 \%, 25 \%$ and $30 \%$. The results of this study showed that the group of dried palm flour extract dose $30 \%$ have the same inhibition capability with positive control (Na Diklofenak) and have greater inhibition capability compared to the dose $20 \%$ and $25 \%$.

Keywords: sugar palm midrib, Caragenan Induction Method, Anti-Inflammatory

\section{PENDAHULUAN}

Indonesia sendiri kaya akan berbagai keanekaragaman hayati yang berpotensi untuk dikembangkan sebagai obat atau bahan baku obat. Hal tersebut menunjukkan besarnya peran dan potensi bahan alam dalam proses pencarian dan pengembangan bahan obat. Pada saat ini penggunaan bahan alam sebagai obat cenderung meningkat. Penelitian terhadap berbagai tumbuhan terus dilakukan terutama untuk pengobatan tradisional.

Aren (Arenga pinanta) merupakan sumber daya hayati yang banyak dimanfaatkan oleh masyarakat. Tumbuhan aren banyak tumbuh di daerah tropis seperti Sulawesi Utara. Tumbuhan aren sangat bermanfaat dalam kehidupan, hampir setiap bagian dapat dimanfaatkan, seperti air nira hasil sadapan dapat dijadikan sebagai bahan utama pembuatan minuman beralkohol dan gula aren, buahnya dapat dijadikan sebagai kolang-kaling, ijuk dijadikan sebagai bahan dasar sapu ijuk dan tulang pada daun digunakan sebagai bahan dasar sapu lidi oleh masyarakat sekitar (Hatta, 1993).

Inflamasi merupakan suatu proses protektif normal terhadap trauma fisik atau zatzat mikrobiologik yang bisa menyebabkan terjadinya luka jaringan (Mycek, 2001). Antiinflamasi adalah sebutan untuk agen/obat yang bekerja melawan atau menekan proses peradangan (Dorlan, 2002). Pengujian antiinflamasi dengan metode induksi karegenan pada telapak kaki tikus putih sudah banyak digunakan. Menurut Chakraborty dkk (2004), metode ini merupakan standar metode yang digunakan untuk penelitian antiinflamasi. Kelebihan dari metode ini yaitu pengukuran udem dapat dilakukan lebih akurat dengan mengukur pada bagian telapak kaki tikus yang mengalami udem secara langsung dan mudah diamati pembentukannya (Vogel, 2002). Udem 
adalah pembengkakan pada anggota tubuh yang terjadi karena penimbunan cairan di dalam jaringan. Beberapa area tubuh yang mudah dikenali saat mengalami udem adalah tangan, lengan, kaki dan pergelangan kaki.

Salah satu tumbuhan obat yang digunakan adalah gabah pelepah aren. Menurut Hasil penelitian Sangi dkk (2012) yang berjudul Uji Toksisitas dan Skrining Fitokimia Tepung Gabah Pelepah Aren (Arenga pinnata), tepung pelepah aren bersifat toksik dan mengandung senyawa metabolit sekunder yaitu tanin, fenolik dan flavonoid, yang merupakan senyawa yang berperan sebagai antioksidan. Diketahui flavonoid berfungsi sebagai antiinflamasi dengan cara menghambat enzim siklooksigenase dan lipooksigenase sehingga dapat digunakan untuk mengobati peradangan dan alergi. Flavonoid dalam bentuk aglikon bersifat nonpolar, sedangkan dalam bentuk glikosida bersifat polar. Pemanfaatan gabah pelepah aren sebagai obat tradisional ini belum ada dilaporkan dalam literatur.

Penelitian ini akan dilakukan pengujian untuk mengetahui aktivitas anti-inflamasi ekstrak etanol pelepah aren dengan metoda induksi Udem dengan karagenan pada telapak kaki tikus. Etanol merupakan pelarut polar yang banyak digunakan untuk mengekstrak komponen polar suatu bahan alam dan dikenal sebagai pelarut universal. Komponen polar dari suatu bahan alam dalam ekstrak etanol dapat diambil dengan teknik ekstraksi melalui proses pemisahan. Pelarut yang digunakan yaitu etanol hasil redestilasi captikus karena etanol adalah pelarut yang aman dan tidak toksik

\section{BAHAN DAN METODE}

\section{Alat dan bahan}

Alat-alat yang digunakan dalam penelitian ini adalah alat untuk maserasi, oven, rotary evaporator, timbangan analitis, inkubator, cawan porselin, sudip, labu ukur, vortex, plestimometer, corong pisah dan alat gelas penunjang lainnya. Bahan yang digunakan dalam penelitian adalah tepung pelepah aren diambil dari Bitung, Sulawesi Utara, etanol pa, cap tikus, karagenan 1\%, Natrium diklofenak, CMC $1 \%$, dan akuades. Hewan percobaan yang digunakan adalah tikus putih jantan galur Sprague dawley berumur 3 bulan dengan berat
150-200 g dan sehat yang diambil dari Kec. Airmadidi, Kabupaten Minahasa Utara.

\section{Ekstraksi}

Sebanyak $1.5 \mathrm{~kg}$ tepung pelepah daun aren dimaserasi menggunakan etanol hasil redestilasi cap tikus selama 2 × 24 jam, disaring kemudian dipekatkan menggunakan rotary evaporator. Ekstrak etanol yang diperoleh kemudian disimpan.

\section{Uji aktivitas anti-inflamasi}

Uji aktivitas anti-inflamasi mengikuti (Sutrisna dkk., 2010), hewan uji yang digunakan untuk pengujian sebanyak 15 ekor tikus putih jantan galur wistar dengan berat 150-200 g dibagi dalam 5 kelompok perlakuan yang tiap kelompok terdiri dari 3 ekor. Semua tikus diadaptasi terhadap lingkungan minimal 1 minggu. Sebelum dilakukan pengujian hewan uji dipuasakan selama 18 jam (minum tetap diberikan) sebelum pengujian. Satu jam sebelum pengujian pemberian ekstrak etanol tepung pelepah aren, kelompok kontrol positif (Natrium Diklofenak) dan kontrol negatif (CMC 1\%), masing-masing tikus diinduksi karagenan $1 \%$ sebanyak $0,5 \mathrm{ml}$ pada salah satu kaki secara subplantar. Perlakuan pada tikus putih jantan dilakukan secara peroral sesuai berat badan tikus dengan menggunakan jarum sonde. Kelompok I: diberi CMC 1\% (kontrol negatif) dalam $100 \mathrm{ml}$ Aquades, Kelompok II: diberi natrium diklofenak (kontrol positif) dengan dosis sesuai berat badan tikus, Kelompok III: diberi dosis ekstrak etanol tepung pelepah aren 20\% sebanyak $20 \mathrm{mg}$ ekstrak eatnol tepung pelepah aren, sisanya $80 \%$ larutan CMC, Kelompok IV: diberi dosis ekstrak etanol tepung pelepah aren $25 \%$ sebanyak $25 \mathrm{mg}$ ekstrak etanol tepung pelepah aren, sisanya $75 \%$ larutan CMC, Kelompok V: Diberi dosis ekstrak etanol tepung pelepah aren 30\% sebanyak $30 \mathrm{mg}$ ekstrak etanol tepung pelepah aren, sisanya $70 \%$ larutan CMC, Volume udem kaki tikus diukur selama 6 jam dengan interval waktu pengukuran setiap 1 jam menggunakan alat pengukur (gelas ukur).

\section{Analisa data}

Data yang diperoleh dari hasil penelitian dianalisis menggunakan program statistika metode SPSS ver.16. untuk mengetahui ada tidaknya efek antar perlakuan diuji dengan oneway ANOVA (Analisis of Variance), 
kemudian dilanjutkan dengan uji LSD untuk melihat perbedaan yang nyata antar perlakuan.

\section{HASIL DAN PEMBAHASAN}

\section{Ekstraksi}

Serbuk pelepah aren diekstraksi dengan metode maserasi dengan menggunakan pelarut etanol (hasil redestilasi cap tikus) karena dapat melarutkan senyawa yang bersifat polar maupun semi polar. Maserat yang diperoleh kemudian dipekatkan dengan rotary evaporator. Hasil dari 2-3 kali ekstraksi berupa cairan kental dengan rendemen sebesar $3 \%$.

\section{Uji aktivitas anti-inflamasi}

Uji aktivitas antiinflamasi dilakukan dengan menggunakan metode induksi karagenan $1 \%$ sebanyak $0,5 \mathrm{ml}$ pada telapak kaki tikus. Metode ini merupakan salah satu metode pengujian aktivitas antiinflamasi yang paling sederhana, mudah dilakukan dan sering dipakai. Volume udem diukur sebelum dan sesudah pemberian zat yang di uji menggunakan gelas ukur. Pada uji ini menggunakan 15 ekor tikus dibagi menjadi 5 kelompok uji yaitu kontrol negative (CMC 1\%), kontrol positif (Natrium Diklofenak), ekstrak etanol tepung pelepah aren $20 \%$, ekstrak etanol tepung pelepah aren $25 \%$, dan ekstrak etanol tepung pelepah aren $30 \%$. Selanjutnya diperoleh data rerata volume udem, rerata persen udem dan rerata persen inhibisi udem dari jam ke-0 sampai jam ke-6.

\section{Volume udem}

Dari data rerata volume udem dapat dilihat perbedaan antara kelompok Kontrol negative (CMC 1\%) dengan keempat kelompok lainnya yang diinduksi dengan karagenan. Sama halnya dengan kelompok Kontrol Positif, dosis esktrak etanol tepung pelepah aren $20 \%$, dosis ekstrak etanol tepung pelepah aren $25 \%$ dan dosis ekstrak etanol tepung pelepah aren $30 \%$ pada setiap jam setelah penginduksian karagenan, volume udem terus mengalami kenaikan dari jam ke 1 sampai jam ke 3 dan mengalami penurunan pada jam ke 4 sampai jam ke 6. Hal ini menunjukkan bahwa karagenan $1 \%$ sebanyak 0,5 ml telah mampu membentuk udem yang signifikan sehingga dapat dilihat perbedaan antar kelompok uji. Di samping itu, penurunan volume udem setiap kelompok uji pada jam keempat disebabkan karena efek karagenan yang sudah mulai berkurang, dimana pembentukan udem oleh karagenan hanya mampu bertahan selama 5-6 jam dan berangsur-angsur berkurang dalam waktu 24 jam setelah injeksi (Hidayanti dkk., 2008).

Tabel 1. Rerata volume udem $(\mathrm{mL})$

\begin{tabular}{|c|c|c|c|c|c|c|c|}
\hline \multirow{2}{*}{$\begin{array}{l}\text { Kelompok } \\
\text { perlakuan }\end{array}$} & \multicolumn{7}{|c|}{ Rata-rata volume udem (mL) } \\
\hline & $0 \mathrm{Jam}$ & $1 \mathrm{Jam}$ & $2 \mathrm{Jam}$ & $3 \mathrm{Jam}$ & $4 \mathrm{Jam}$ & $5 \mathrm{Jam}$ & $6 \mathrm{Jam}$ \\
\hline Kontrol negatif & $0,25 \pm 0,03$ & $0,87 \pm 0,09$ & $0,79 \pm 0,08$ & $0,73 \pm 0,06$ & $0,63 \pm 0,06$ & $0,54 \pm 0,04$ & $0,52 \pm 0,05$ \\
\hline Kontrol positif & $0,27 \pm 0,03$ & $0,85 \pm 0,02$ & $0,80 \pm 0,00$ & $0,76 \pm 0,01$ & $0,63 \pm 0,11$ & $0,53 \pm 0,09$ & $0,44 \pm 0,06$ \\
\hline EETPA $20 \%$ & $0,30 \pm 0,00$ & $0,88 \pm 0,05$ & $0,84 \pm 0,05$ & $0,79 \pm 0,06$ & $0,74 \pm 0,04$ & $0, .6 \pm 0,01$ & $0,55 \pm 0,03$ \\
\hline EETPA 25\% & $0,29 \pm 0,02$ & $0,87 \pm 0,06$ & $0,83 \pm 0,04$ & $0,76 \pm 0,04$ & $0,65 \pm 0,08$ & $0,57 \pm 0,05$ & $0,43 \pm 0,06$ \\
\hline EETPA $30 \%$ & $0,31 \pm 0,08$ & $0,76 \pm 0,08$ & $0,71 \pm 0,08$ & $0,68 \pm 0,10$ & $0,62 \pm 0,12$ & $0,56 \pm 0,08$ & $0,50 \pm 0,08$ \\
\hline
\end{tabular}

Kontrol negatif: CMC 1\%, kontrol positif: natrium diklofenak dan EETPA: ekstrak etanol tepung pelepah aren dengan konsentrasi 20, 25 dan 30\%

\section{Peningkatan volume udem}

Peningkatan volume udem dilakukan untuk membandingkan volume dasar sebelum dan sesudah menyuntikkan karagenan dalam satuan persen. Hasil peningkatan volume udem disajikan pada gambar 2. Berdasarkan gambar 2 dapat dilihat bahwa pada kelompok kontrol negatif persentase udem yang terbentuk sangat tinggi dan terus mengalami penurunan yang signifikan dari jam ke-4 sampai jam ke-5. Hal ini disebabkan karena hewan uji hanya diberikan suspensi CMC 1\% yang tidak mampu menghambat pembentukan udem dan respon terhadap udem hanya mengandalkan imunitas tikus. Jika dibandingkan dengan kelompok kontrol positif, kelompok ekstrak etanol tepung pelepah aren $30 \%$, peningkatan volume udem yang terbentuk lebih rendah pada jam ke-1 sampai jam ke-4. Hal ini disebabkan karena kontrol positif merupakan obat yang berfungsi sebagai anti-inflamasi sedangkan untuk kelompok dosis ekstrak etanol tepung pelepah 
aren 20\%, 25\% dan 30\% diberikan ekstrak etanol yang diduga bersifat sebagai antiinflamasi. Menurut Sangi dkk (2012) tepung dari pelepah aren mengandung senyawa fitokimia diantaranya alkaloid, tannin, dan triterpenoid selain itu tepung pelepah aren juga bersifat toksisitas dan juga adanya senyawa flavonoid yang terkandung di dalamnya yang diduga bersifat sebagai antiinflamasi. Diketahui flavonoid berfungsi sebagai antiinflamasi dengan cara menghambat enzim siklooksigenase dan lipooksigenase sehingga dapat digunakan untuk mengobati peradangan dan alergi. Zainudin (2015) menyatakan bahwa pelepah aren mengandung senyawa saponin, steroid, flavanoid dan memiliki potensi sebagai antioksidan.

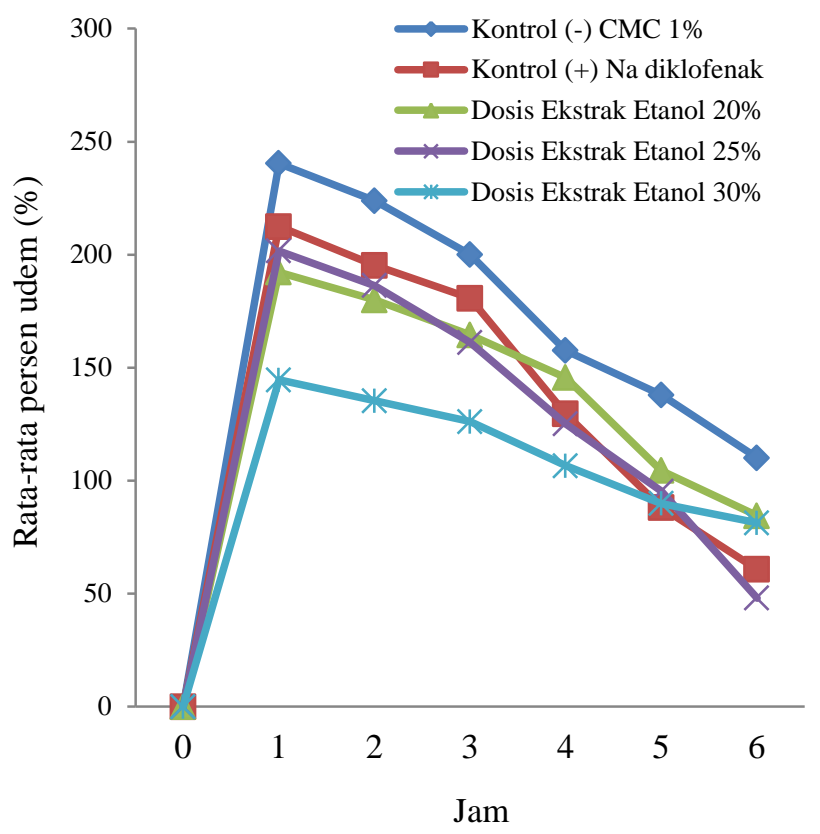

Gambar 2. Grafik hubungan persen udem terhadap waktu

Selanjutnya untuk melihat aktivitas antiinflamasi setiap kelompok dalam menghambat pembentukan udema dapat dihitung rerata persentase inhibisi udema.

\section{Persen inhibisi udem}

Perhitungan persen inhibisi udem dihitung dilakukan untuk melihat seberapa besar penghambatan ekstrak etanol tepung pelepah aren terhadap peredangan pada telapak kaki tikus. Hasil persen inhibisi udem disajikan pada gambar 3. Berdasarkan gambar 3 diketahui bahwa kelompok dosis 30\% mempunyai persen inhibisi udem lebih besar dibandingkan dosis kontrol positif, kelompok ekstrak etanol 20\% dan 25\% pada jam ke-1 sampai jam ke-5. Sedangkan pada jam ke-6 kelompok ekstrak etanol 25\% mempunyai persen inhibisi udem yang paling tinggi. Kontrol positif mempunyai persen inhibisi udem yang paling rendah pada jam ke-1 sampai jam ke-3 sedangkan pada jam ke-4, jam ke-5 dan jam ke-6 dosisi ekstrak etanol $20 \%$ memiliki inhibisi udem yang paling rendah.

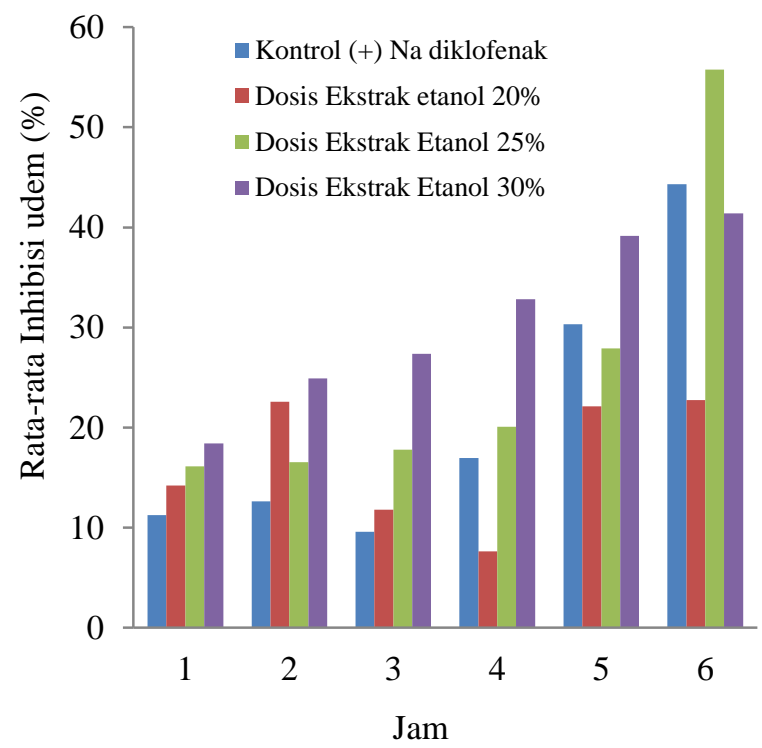

Gambar 3. Grafik Hubungan Rata-rata persen inhibisi udem (\%) terhadap Waktu

Hasil uji statistik BNT menunjukkan bahwa kelompok dosis ekstrak etanol 30\% mempunyai persen inhibisi yang sama dengan kontrol positif dan mempunyai persen inhibisi yang lebih besar dibandingkan kelompok $20 \%$ dan 25\% . Menurut Nescas (2013) Proses pembentukan udem yang diinduksi oleh karagenan terjadi dalam dua fase dan melibatkan beberapa mediator inflamasi. Fase pertama terjadi selama 3 jam setelah induksi karagenan dimana terjadi pelepasan mediator histamin, serotonin, bradikinin dan peningkatan sintesis prostaglandin disekitar jaringan yang luka. Fase kedua terjadi mulai dari jam keempat sampai jam kelima dan terjadi pelepasan prostaglandin, protease dan lisosom. Umumnya fase kedua ini sensitif terhadap obat-obat antiinflamsi.

Berdasarkan hal tersebut maka diketahui bahwa dosisi $30 \%$ mampu berkerja sebagai antiinflamasi sebaik kontrol positf pada fase pertama dan fase kedua. Penurunan dosis akan menimbulkan kerja anti-inflamasi kurang maksimal. 


\section{KESIMPULAN}

Hasil penelitian aktivitas anti-inflamasi ekstrak etanol tepung pelepah aren ini menunjukkan kelompok ekstrak etanol tepung pelepah aren dosis 30\% memiliki kemampuan inhibisi udem yang sama dengan 127 ontrol positif (Na diklofenak) dan memiliki kemampuan inhibisi yang lebih besar dibandingkan dosis $20 \%$ dan $25 \%$.

\section{DAFTAR PUSTAKA}

Chakraborty, A., Devy, R.K.B., Devi, Rita, S., Sharatchandra, Kh. \& Singh, Th.I. 2004. Preliminary studies on anti-inflammatory and analgesic activities of spilanthes acmella in experimental animal models. Indian Journal Pharmacology. 36(3), 148150.

Hatta, S. 1993. Aren Budidaya dan Multigunanya. Kanisius, Yogyakarta.

Necas, J.L. 2013. Carrageenan: a review. Veterinarni Medicina. 58(4), 187-205.
Sangi, M., Momuat, L. \& Kumaunang, M. 2012. Uji toksisitas dan skrining fitokamia tepung gabah pelepah aren (Arenga pinnanta). Jurnal Ilmiah Sains. 12(2), 128-134.

Setyawan, A.D., Listyawati, S. \& Hidayati, N.A. 2008. Kandungan kimia dan uji antiinflamasi ekstrak etanol Lantana camara L. pada tikus putih (Rattus norvegicus L.) jantan. Bioteknologi. 5(1), 10-17.

Sutrisna, E.M., Wahyuni, A.S. \& Azmi, U. 2010. Efek ekstrak etanol daging buah mahkota dewa (Phaleria macrocarpa (Scheff.) Boerl.) terhadap penurunan kadar asam urat pada mencit putih jantan yang diinduksi potassium oxonate. Jurnal Pharmacon. 11(2), 62-69.

Zainudin, A., Hasanah, U. \& Pemana, Y.R. 2015. Uji aktivitas diuretik ekstrak akar aren (Arenga pinnanta) terhadap tikus putih galur wistar (Rattus norvgicus) Dengan pembanding furosemid. Jurnal Kesehatan Prima. 9(1), 1403-1411. 